\title{
Preparation and Mechanical Properties of Ultra-High-Strength Nanocrystalline Metals
}

Ivo Marek ${ }^{1}$, Dalibor Vojtěch ${ }^{1}$, Alena Michalcová ${ }^{1}$, Tomáš František Kubatík ${ }^{2}$

${ }^{1}$ Department of Metals and Corrosion Engineering, University of Chemistry and Technology, Technická 5, 166 28, Prague 6. Czech Republic.E-mail: Ivo.Marek@vscht.cz, Dalibor.Vojtech@vscht.cz, Alena.Michalcova@ vscht.cz

${ }^{2}$ Institute of Plasma Physics AS CR, v.v.i., Za Slovankou 1782/3, 182 00, Prague 8. Czech Republic. E-mail: kubatik@ipp.cas.cz

Keywords: nanocrystalline materials, silver, selective leaching, spark plasma sintering, mechanical properties

Nanomaterials are advanced materials exhibiting unique mechanical, chemical and physical properties due to their structural constituents having size less than $100 \mathrm{~nm}$. Such materials are suitable for using in wide field of possible applications e.g. special structural applications, catalysis, biomedicine or electronics. There are many methods how to produce nanocrystalline materials or nanoparticles including vapor, liquid and solid processing routes. In this work, ultra-high-strength nanocrystalline silver was prepared by combination of selective leaching and subsequent consolidation by spark plasma sintering. Conventional cast silver was used as reference materials.

\section{Acknowledgement}

Research on nano-crystalline metals is financially supported by the Czech Science Foundation (project no. P108/12/G043) and MSMT (project no. 20/2015).

\section{References}

[1] TJONG S.C. (2006). Nanocrystalline materials: Their Synthesis-Structure-Property Relationship and Applications, pp. 241-271. Elsevier, ISBN: 008047960X. Kidlington, Oxford, UK.

[2] WANG, Y., CHEN, M., ZHOU, F., MA, E. (2002). High tensile ductility in a nanostructured metal. In: Nature, Vol. 419, pp. 912-915.

[3] MEYERS, M.A., MISHRA, A., BENSON, D.J. (2006). Mechanical properties of nanocrystalline materials. In: Progress in Materials Science, Vol. 51, pp. 427-556.

[4] GUTMANAS, E.Y., TRUSOV, L.I., GOTMAN, I. (1994). Consolidation, microstructure and mechanical properties of nanocrystalline metal powders. In: NanoStructured Materials, Vol. 4, No. 8, pp. 893-901.

[5] KUMAR, K.S., VAN SWYGENHOVEN, H., SURESH, S. (2003). Mechanical behavior of nanocrystalline metals and alloys. In: Acta Materialia, Vol. 51, pp. 5743-5774.

[6] TJONG, S.C., HAYDN, Ch. (2004). Nanocrystalline materials and coatings. In: Materials Science and Engineering $R$, Vol. 45, pp. 1-88.

[7] XIANG, Y., CHEN, X., VLASSAK, J.J. (2002). The mechanical properties of electroplated Cu thin films measured ny means of the bulge test technique. In: Materials Research Society Symposium Proceedings, Vol. 695, pp. L4.9.

[8] CARLTON, C.E., FERREIRA, P.J. (2007). What is behind the inverse Hall-Petch effect in nanocrystalline materials?. In: Acta Materialia, Vol. 55, pp. 3749-3756.

[9] GUPTA, M., TAY, A.A.O., VAIDYANATHAN, K., SRIVATSAN, T.S. (2007). An investigation of the synthesis and characterization of copper samples for use in interconnect applications. In: Materials Science and Engineering A, Vol. 454-455, pp. 690-694.

[10]MEYERS, M.A., MISHRA, A., BENSON, D.J. (2006). The deformation physics of nanocrystalline metals: Experiments, analysis, and computations. In: JOM, pp. 41-48.

[11] VOJTECH, D., MICHALCOVA, A., PRUSA, F., DAM, K., SEDA, P. (2012). Properties of the thermally stable $\mathrm{Al}_{95} \mathrm{Cr}_{3.1} \mathrm{Fe}_{1.1} \mathrm{Ti}_{0.8}$ alloy prepared by cold-compression at ultra-high pressure and by hot-extrusion. In: Materials Characterization, Vol. 66, pp. 83-92.

[12] OKUYAMA, K., LENGGORO, I.W. (2003). Preparation of nanoparticles via spray route. In: Chemical Engineering Science, Vol. 58, pp. 537-547.

[13]JIN, Z., XIAO, M., BAO, Z., WANG, P., WANG, J.F. (2012). A general approach to mesoporous metal oxide microspheres loaded with noble metal nanoparticles. In: Angewandte Chemie International Edition, Vol. 51, pp. 6406-6410. 
[14]SONDI, I., SALOPEK-SONDI, B. (2004). Silver nanoparticles as antimicrobial agent: a case study on E. coli as a model for Gram-negative bacteria. In: Journal of Colloid and Interface Science, Vol. 275, pp. 177-182.

[15]DAMONTE, L.C., MENDOZA ZELIS, L.A., MARI SOUCASE, B., HERNANDEZ FENOLLOSA, M.A. (2004). Nanoparticles of $\mathrm{ZnO}$ obtained by mechanical milling. In: Powder Technology, Vol. 148, pp. 15-19.

[16]VOJTECH, D., MICHAlCOVA, A., KLEMENTOVA, M., SERAK, J., MORTANIKOVA, M. (2009). Nanocrystalline nickel as a material with high hydrogen storage capacity. In: Materials Letters, Vol. 63, pp. 10741076.

[17]TJONG, S.C., CHEN, H. (2004). Nanocrystalline materials and coatings. In: Materials Science Engineering $R$, Vol. 45, pp. 1-88.

[18] VOJTECH, D., PRUSA, F. (2012). Application of powder metallurgy in the processing of aluminium scraps with high-iron contents. In: Materiali in Tehnologije, Vol. 46, pp. 339-343.

[19]VOJTECH, D., MICHALCOVA, A., PILCH, J., SITTNER, P., SERAK, J., NOVAK, P. (2009). Structural characteristics and thermal stability of $\mathrm{Al}-5.7 \mathrm{Cr}-2.5 \mathrm{Fe}-1.3 \mathrm{Ti}$ alloy produced by powder metallurgy. In: Journal of Alloys and Compounds, Vol. 475, pp. 151-156.

[20]YE, J., AJDELSZTAJN, L., SCHOENUNG, J.M. (2006). Bulk Nanocrystalline Aluminum 5083 Alloy Fabricated by a Novel Technique: Cryomilling and Spark Plasma Sintering. In: Metallurgical and Materials Transactions A, Vol. 37, pp. 2569-2579.

[21]GU, J., GU, S., XUE, L., WU, S., YAN, Y. (2012). Microstructure and mechanical properties of in-situ $\mathrm{Al}_{3} \mathrm{Fe}_{4} / \mathrm{Al}$ composites prepared by mechanical alloying and spark plasma sintering. In: Materials Science and Engineering A, Vol. 558, pp. 684-691.

[22]MENDIS, C.L., JHAWAR, H.P., SASAKI, T.T., OH-ISHI, K., SIVAPRASAD, K., FLEURY, E., HONO, K. (2012). Mechanical properties and microstructures of Al-1Fe-(0-1)Zr bulk nano-crystalline alloy processed by mechanical alloying and spark plasma sintering. In: Materials Science and Engineering A, Vol. 541, pp. 152-158.

[23] AKINRINLOLA, B., GAUVIN, R., BROCHU, M. (2012). Improving the mechanical reliability of cryomilled AlMg alloy using a two-stage spark plasma sintering cycle. In: Scripta Materialia, Vol. 66, pp. 455-458. 